\title{
Pelatihan Strategi E-Promotion Pariwisata 1000 Musamus Kampung Salor Distrik Kurik Kabupaten Merauke
}

\author{
Paul Adryani Moento*1, Fitriani2 \\ 1,2Jurusan Ilmu Administrasi Negara, Fakultas Ilmu Sosial dan Ilmu Politik, Universitas Musamus, \\ Indonesia \\ *e-mail: paulmoento@unmus.ac.id ${ }^{1}$
}

\begin{abstract}
Abstrak
Pariwisata sangat penting bagi pembangunan pemerintah daerah, maka dibutuhkan suatu strategi dalam mempromosikan potensi wisata yang ada. Kabupaten Merauke memiliki destinasi wisata yang cukup banyak dan tersebar di beberapa wilayah distrik, salah satunya adalah objek wisata 1000 Musamus yang berada di wilayah Kampung Salor Distrik Kurik, namun sampai saat ini belum optimal promosinya, sehingga belum dikenal di Indonesia dan Dunia. Pengabdian ini bertujuan untuk melatih pengelola ojek wisata 1000 Musamus dan pegawai distrik yang mengurusu pemmbangunan pariwisata di wilayah Distrik Kurik Kabupaten Meruake, sehingga dapat mengoptimalkan ketersediaan jaringan internet yang sudah ada di wilayah tersebut. Metode yang gunakan dalam pengabdian ini yaitu pendekatan pemberian materi serta pelatihan untuk menghasilkan arah yang telah di tetapkan. Pengabdian telah diaksanakan dengan para peserta mendapatkan materi Undang- undang No. 19 Tahun 2018 Tentang Perubahan Atas Undang-undang No. 11 Tahun 2008 Tentang Informasi Dan Transaksi Elektronik, kemudian, peserta mendapatkan materi cara mendapatkan hak paten dan para peserta mendapatkan materi tentang youtube dan pelatihan cara pembuatan akun youtube serta peserta mendapatkan materi tentang website serta di berikan pelatihan cara mengelola website.
\end{abstract}

Kata kunci: Pariwisata, Promosi, Strategi

\begin{abstract}
Tourism is very important for the development of local governments, so a strategy is needed in promoting the potential of existing tourism. Merauke Regency has quite a lot of tourist destinations and is spread across several districts, one of which is the 1000 Musamus tourist attraction located in the Kampung Salor area of Kurik District, but until now it has not been optimal promotion, so it is not yet known in Indonesia and the World. This service aims to train 1000 Musamus tourist motorcycle taxi managers and district employees who take care of tourism development in the Kurik District area of Meruake Regency, so as to optimize the availability of existing internet networks in the region. The method used in this devotion is the approach of giving materials and training to produce the direction that has been set. Devotion has been entrusted with the participants getting the material of Law No. 19 of 2018 On Changes to Law No. 11 of 2008 On Information and Electronic Transactions, then, participants get material on how to get patents and participants get material about youtube and training how to create a youtube account and participants get material about the website and are given training on how to manage the website.
\end{abstract}

Keywords: Promotion, Strategy, Tourism

\section{PENDAHULUAN}

Konten Perkembangan teknologi, informasi, dan komunikasi yang terus meningkat membuat jumlah pengguna internet juga semakin tinggi di seluruh dunia setiap tahunnya, tak terkecuali Indonesia. Pusat Kajian Komunikasi UI melakukan rilis pers tentang hasil survei profil pengguna internet di Indonesia. Hasil survei ini merupakan hasil kerja sama dengan APJII yang merupakan sumber informasi tentang data pengguna internet di Indonesia saat ini (Puskakom, 2015). Survei tersebut menyebutkan bahwa jumlah pengguna internet di Indonesia telah mencapai 88,1 juta pengguna. Jumlah pengguna internet yang tinggi menjadikan Indonesia sebagai pasar yang potensial untuk kegiatan bisnis secara online. T entu saja ini menjadi peluang besar bagi para pelaku bisnis dalam melakukan kegiatan promosi, tak terkecuali pemerintah yang berupaya mempromosikan Indonesia melalui media sosial. Cara penggunaan yang mudah dan tidak memerlukan biaya yang besar, dengan menekankan pada bentuk visual atau gambar, 
adanya fitur hashtag yang mempermudah pencarian, dan jumlah pengguna yang cepat meningkat, instagram dapat dijadikan strategi marketing yang jitu bagi Kementerian Pariwisata Indonesia dalam mempromosikan berbagai keindahan dan budaya yang dimiliki Indonesia. Promosi pariwisata dalam negeri dengan menggunakan media sosial merupakan hal yang menarik karena biasanya pemerintah melakukan promosi pariwisata dengan mendatangi negara dan kota yang jauh dengan menghabiskan biaya tinggi. Kini promosi dapat dilakukan dengan mengunggah foto atau video yang dapat menarik wisatawan untuk datang berwisata ke Indonesia tanpa harus mengeluarkan biaya yang banyak dan menguras waktu.Dengan koneksi internet semua dapat terjadi dalam waktu kurang dari satu menit.

Komunikasi merupakan salah satu aspek penting dalam pemasaran sektor pariwisata suatu daerah. Menurut Soemanagara, pentingnya pemahaman tentang komunikasi ini ditujukan agar informasi yang disampaikan dapat memberikan dampak yang diinginkan dan mencapai sebuah kesamaan kehendak. Aplikasi komunikasi dalam pemasaran disebut komunikasi pemasaran. Soemanagara menyebutkan, komunikasi pemasaran bertujuan untuk mencapai tiga tahap perubahan yang ditujukan kepada konsumen, antara lain perubahan knowledge (pengetahuan), perubahan sikap, dan perubahan perilaku (Soemanagara, 2008). Komunikasi pemasaran merupakan sebuah usaha untuk menyampaikan pesan kepada publik terutama konsumen mengenai keberadaan suatu produk/ jasa di pasar. (Machfoedz, 2010) menyatakan bahwa komunikasi pemasaran adalah istilah yang digunakan untuk menerangkan arus informasi tentang produk dari pemasar sampai kepada konsumen. Pemasar menggunakan iklan, pemasaran langsung, publisitas, promosi penjualan, dan penjualan langsung untuk memberikan informasi yang mereka harapkan dapat memengaruhi keputusan pembelian oleh konsumen.

Menurut (Rangkuti, 2013) bauran promosi (promotion mix) merupakan bagian dari bauran pemasaran (marketing mix) itu sendiri yang secara umum terdiri atas product, place, price, promotion, people, process serta physical evidence. Meskipun secara umum bentukbentuk promosi memiliki fungsi yang sama, bentuk-bentuk tersebut dapat dibedakan berdasarkan tugas-tugas khususnya. Beberapa tugas khusus itu atau sering disebut bauran promosi (promotion mix) adalah 1) advertising periklanan yaitu komunikasi nonindividu dengan sejumlah biaya, melalui berbagai media yang dilakukan oleh perusahaan, lembaga nirlaba, serta individu; 2) sales promotion, merupakan salah satu kegiatan promosi untuk melakukan rangsangan kepada konsumen untuk melakukan pembelian; 3) personal selling yaitu interaksi antara individu, saling bertemu muka yang ditujukan untuk menciptakan, memperbaiki, menguasai, atau mempertahankan hubungan pertukaran yang saling menguntungkan dengan pihak lain; 4) direct marketing merupakan kegiatan penjualan secara langsung kepada konsumen untuk melakukan pembelian; 5) public relationship usaha untuk merangsang permintaan terhadap suatu produk secara nonpersonal dengan membuat berita yang bersifat komersial tentang produk tersebut dalam media tercetak atau bukan, maupun hasil wawancara yang disiarkan dalam media tersebut. Menurut (Swastha, B, Irawan, 2006) dikemukakan tujuan promosi adalah :

a. modifikasi tingkah laku,

b. memberi tahu,

c. membujuk, dan

d. mengingatkan.

Menurut (Alma, 2014) langkah-langkah yang diperlukan sebagai berikut.

1. Tentukan segmen pasar tempat strategi akan diarahkan, yaitu:

a. negara atau daerah yang merupakan pasar potensial dan cara hidup masyarakat tertentu diharapkan menjadi konsumen,

b. kelas sosial, tingkat pendidikan, dan cara hidup masyarakat tertentu,

c. tingkat penghasilan yang dimiliki masyarakat setelah dikurangi kebutuhan pokok,

d. anggota masyarakat yang mempunyai waktu luang.

e. keluarga-keluarga yang tidak banyak mempunyai anak ataupun khusus ditujukan kepada kelompok anak-anak.

2. Harus diketahui apa yang menjadi perhatian atau selera dari masyarakat konsumen 
3. Perhatikan faktor-faktor yang dapat mendorong permintaan konsumen, seperti fasilitas, kemudahan, faktor harga, faktor produk itu sendiri, dan pelayanan waktu yang tepat.

4. Perhatikan pula bahwa ada dua lembaga penting dalam pemasaran industri pariwisata yang perlu diperhatikan yaitu:

a. perantara, seperti agen perjalanan,

b. konsumen akhir, wisatawan, kaum pedagang yang senang bepergian, orang yang akan mengadakan konferensi, rapat kerja, dan sebagainya

Menurut (Atiko, G., Sudrajat, R. H., \& Nasionalita, 2016) media sosial adalah platform media yang memfokuskan pada eksistensi pengguna yang memfasilitasi mereka dalam beraktivitas maupun berkolaborasi.Oleh karena itu, media sosial dapat dilihat sebagai medium (fasilitator) online yang menguatkan hubungan antarpengguna sekaligus sebagai sebuah ikatan sosial. Perkembangan pariwisata yang cukup pesat di Indonesia umumnya serta di Provonsi Papua khususnya telah membawa banyak perubahan terutama dalam konsep dan tujuan berwisata.Wisatawan tidak lagi hanya cukup menikmati keindahaan alam tempat wisata dengan segala fasilitas wisatanya. Sekarang ini banyak wisatawan yang juga ingin menikmati keleluasaan berwisata dengan cara berinteraksi langsung dengan lingkungan dan masyarakat lokal. Perubahan inilah yang mendorong muculnya konsep pariwisata pedesaan yang ditandai dengan munculnya desa-desa wisata di berbagai provinsi di Indonesia (Olivia \& Widarti, 2021).

Desa wisata didefinisikan secara beragam. Salah satu pemahaman tentang wisata desa adalah suatu bentuk lingkungan yang memiliki ciri khusus, baik alam maupun budaya yang sesuai dengan tuntutan wisatawan, di mana mereka dapat menikmati mengenal, menghayati dan mempelajari kekhasan desa beserta segala daya tariknya (Setiawan \& U., 2014). Salahsatu karakteristik Kabupaten Merauke Provinsi Papua adalah musamus yaitu rumah semut yang dapat tumbuh mencapai 5 meter dengan diameter lebih dari 2 meter, dan tersebar di beberapa titik wilayah salahsatunya adalah di Kampung Salor Distrik Kurik. Areal keberadaan musamus tersebut berada pada padang savana yang merupakan lahan kritis yang hanya dapat ditumbuhi tanaman penghasil yaitu pohon jambu mete. Luas padang savana tersebut sekitar 29 hektar yang direncanakan untuk pemanfaatan areal pariwisata, adapun tahap awal sudah dilakukan penggunaannya sekitar 6 hektar, dengan diawali rembuk bersama 29 kepala keluarga pemilik lahan, yang ditindak lanjuti dengan bantuan jasa konsultan untuk membuat design master plan. Setelah itu dilanjutkan dangan tahap sosilaisasi yang melibatkan masayrakat kampung, pihak pemilik lahan, Bamuskam, masyarakat serta tokoh agama setempat. Langkah selanjutnya yang akan dilakukan saat ini berupa pembangunan infrastruktur jalan akses masuk areal sepanjang 900 meter berupa penimbunan sermat, pembangunan Honai-Honai peristirahatan wisatawan serta pembangunan tower sehingga pengunjung dapat menikmati pemandangan Musamus dari atas. Termasuk hamparan padi, dengan sumber dana berasal dari dana desa sebesar 250 juta. Pada tahun 2019 ini, sebanyak 87 juta dialokasikan pihak kampung untuk pengembangan wisata air mengusung konsep sepeda air bebek dan perahu tradisional pada Waduk Wawan sebagai spot guna mendukung wisata Musamus.

Areal tersebut merupakan tanah ulayat milik Yohanis Mahuze dan telah dilakukan kesepakatan bersama Pemerintah Kampung terkait pola pemanfaatan yang menghasilkan keuntungan dan kemandirian ekonomi masyarakat.Baik itu pihak kampung, masyarakat pemilik hak ulayat, masyarakat pemilik lahan Musamus serta membuka lahan pekerjaan bagi masyarakat setempat. Musamus selain itu menjadi icon kampung serta menambah khasanah dunia kepariwisataan Kabupaten Merauke. Permasalahan yang menjadi kendala saat ini adalah keterbatasan dana pendukung yang dikelola Kampung, dan dukungan promosi pariwisata yang belum maksimal, pihak mitra (Distrik Kurik) memiliki harapan potensi objek wisata 1000 musamus ini mendapat dukungan jajaran di atas, baik itu pemerintah distrik, SKPD terkait di tingkat kabupaten, pemerintah provinsi maupun pusat. Adapun tujuan pengabdian yang ditetapkan oleh tim pengabdian yaitu untuk memberikan pemahaman mengenai regulasi dalam proses mengembangkan E- Promosi kepariwisataan di wisata 1000 musamus, serta memberikan cara ataupun teknik melakukan promosi wisata 1000 musamus melalui penggunaan teknologi. Tim Penulis berharap kegiatan pengabdian ini dapat mendukung kendala yang ada yaitu promosi pariwisata melalui media-media sosial yang ada, hingga dapat 
memperkenal destinasi wisata yang alami ini ke masyarakat dunia serta mendukung Pemerintah Kabupten Merauke sedang mencoba membangun sektor pariwisata dengan mengembangkan potensi wisata yang ada di wilayahnya.

\section{METODE}

Pada Metode yang digunakan yaitu langkah pertama, Need Assesment, melakukan proses pendekatan kepada objek sasaran dengan berupaya memahami minat obejek sasaran yang di anggap layak (Haryani, 2020). Dalam pengabdian masyarakat ini, proses obeservasi dilakukan terebih dahulu dengan memahami kebutuhan yang di inginkan oleh stakeholder, selanjutnya pemberian materi. Dalam pelatihan ini para peserta di giring untuk memahami aturan serta regulasi dalam strategi E-promosi wisata 1000 musamus, serta melalui proses diskusi tanya jawab antara pemateri dan peserta yang menghasilkan pemahaman mendalam terhadap para peserta. Selanjutnya langkah kedua, capacity building yaitu proses pelatihan secara langsung kepada para peserta (Haryani, 2020). Para peserta di berikan peatihan teknik mengambil video serta gambar, dalam pelatihan ini, para peserta di ajarkan cara mengambi gambar serta video dengan memberikan kebebasan untuk mengambil ojek gambar apa saja yang mereka inginkan terkait dengan strategi E promosi pariwisata. Serta para peserta di berikan pelatihan strategi promosi melalui media sosial berupa youtube dan website. Para peserta diberikan tuntunan terkait cara mengelola akun youtube dari proses pembuatan akun sampai pada melakan pengunggahan video, kemudian peatihan lain yang di berikan yaitu pembuatan akun website sampai pada mengelola akun website untuk kepentingan E-promosi pariwisata. (Batubara et al., 2021). Adapun tahapan pengabdian masyarakat ini yaitu :

1. pemberian materi regulasi kepada para peserta

2. pelatihan pengambilan video dan gambar

3. pelatihan mebuat dan mengelola youtube,serta

4. pelatihan membuat dan mengelola website.

\section{HASIL DAN PEMBAHASAN}

\subsection{Pemberian materi Strategi promosi pariwisata}

Kabupaten Merauke mempunyai tempat wisata yang sangat indah dan unik, tempat wisata terbsebut adalah Wisata 1000 Musamus. Wisata 1000 Musamus ini merupakan aset dan warisan alam yang patut untuk di promosikan. Selain untuk di promosikan perlu juga dilakukan penataan agar menarik minat para wisatawan. Pariwisata menggambarkan salah satu bagian yang tengah serius digarap oleh negara-negara didunia dalam rangka mendorong perekonomian nasional. Indonesia memiliki potensi pariwisata yang besar karena indonesia merupakan sebuah negara kepulauan yang luas, yang wilayahnya membentang dari Sumatera sampai Papua. Pariwisata menggambarkan salah satu fenomena sosial, ekonomi, politik, budaya, dan teknologi, sehingga keadaan ini menjadi sebuah kepedulian yang besar dari para ahli dan perencana pembangunan. Pariwisata adalah segala sesuatu yang berhubungan dengan wisata termasuk juga pengusahaan obyek serta daya tarik wisata dan juga usaha-usaha yang terkait dengan bidang tersebut (Bahiyah \& Hidayat, 2018). Bersamaan dengan perkembangannya timbul pariwisata berbasis penduduk, yakni pariwisata yang menyuguhkan seluruh sumber energi natural yang tidak cuma memajukan aspek kawasan tentang konservasi saja, akan tetapi serta melibatkan kebudayaan serta social warga kurang lebih sehinga memberikan keuntungan kepada warga.

Selanjutnya dalam pengabdian ini di laksanakan pemberian materi tentang strategi pariwisata kepada aparat distrik kurik serta perwakilan BUMK dari kampung salor indah. Materi yang disampaikan berkaitan dengan undang undang informasi dan teknologi yang memiliki makna yaitu memahami aturan aturan dalam promosi pariwisata melalui teknologi.materi yang disampaikan Berdasarkan UU No. 19 Tahun 2018 Tentang Perubahan Atas UU No. 11 Tahun 
2008 Tentang Informasi Dan Transaksi Elektronik. Kemudian tidak hanya itu, materi mengenai undang undang teknologi ini memberikan penekanan kepada peserta agar mereka memahami hal-hal yang di hindari agar tidak menyalahi aturan ketika melakukan promosi wisata secara teknologi.

Adapun materi yang di sampaikan kepada para peserta dalam pengabdian masyarakat ini di urutkan secara deskripstif sebagai berikut : pemberian pemahaman mengenai dasar hukum yang mengandung asas, konten, penegakan hukum. Dalam asas yang di maksudkan pada materi ini yaitu, dalam memanfaatkan teknologi ITE perlu di lakukan atas dasar kejelasan aturan, kemanfaatan, perlu berhati-hati, memiliki etika yang baik, serta beba untuk menentukan teknologi. Asas ini di tekankan kepada para peserta untuk melaksanakan sesuai materi yang diberikan ketika melakukan pengembangan wisata 1000 musamus melalui promosi secara elektronik. Selanjutnya konten, konten yang di maksudkan dalam materi tersebut yaitu, muatan objek yang di visualisasikan ke dalam promosi harus mematuhi aturan undang-undang tentang ,Pengaturan mengenai informasi dan transaksi elektronik. 2. Pengaturan mengenai perbuatan yang dilarang. Kemudian, materi yang di sampaiakn yaitu penegakan hukum ketika dalam mengembangkan wisata 1000 musamus di dapat temuan pelanggaran dalam melakukan promosi wisata akan mendapat tuntutan secara hukum dari pihak kementerian komunikasi dan informasi serta kepoisian negara republik indonesia.

Selanjutnya, pemateri memberikan pemahaman kepada para peserta untuk memahami terkait cara mempatenkan atau meng HAKI-kan merek pariwisata 1000 musamus sesuai aturan UU NO. 20 tahun 2016 tentang Merek dan Indikasi Geografis. Di awali dengan memberikan pemahaman mengenai cara mempatenkan dan mengHakikan merek pariwisata 1000 musamus. Selanjutnya para peserta di berikan materi mengenai urutan mempatenkan logo wisata 1000 musamus yaitu sesuai undang undang nomor 20 tahun 2016 Tentang Merek dan Indikasi Geografis, yaitu, proses pendaftaran merek, syarat yang harus di ikuti, prosedur yang di jalankan, kemduain proses membuat akun, selanjutnya penolakan ketika merek yang di daftarakan di tolak, jangka waktu merek yang dilindungi serta masa perpanjangan merek, kemudian pelanggaran dan gugatan yang terjadi jika ada, serta ketentuan pidana yang di dapatkan jika terjadi.

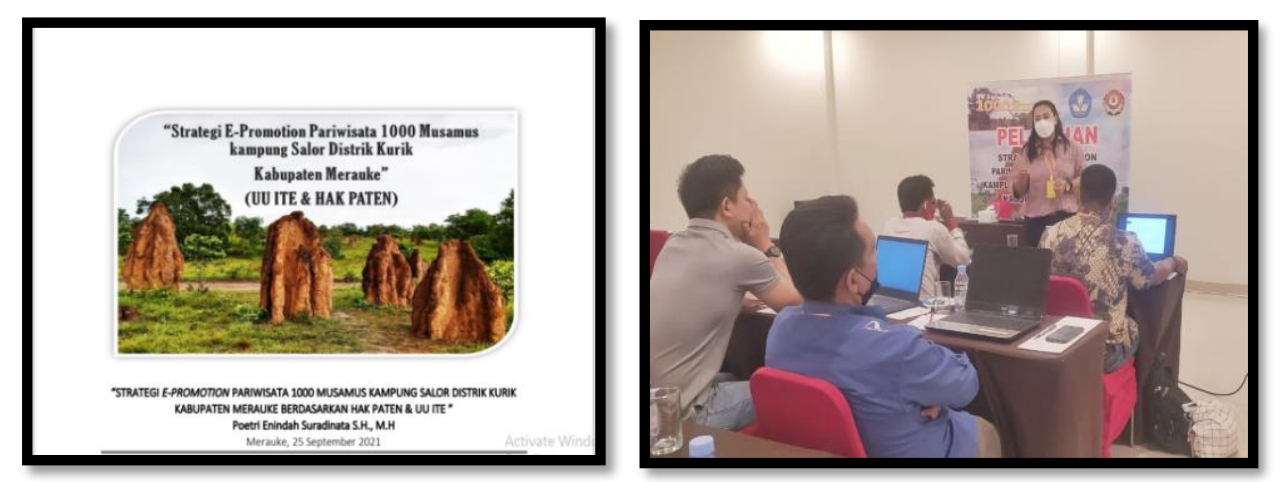

Gambar 1. Kegiatan Pemberian Materi

Gambar di atas menjelaskan bahwa kegiatan pelatihan Strategi E-Promosi Pariwisata 1000 Musamus di Kampung Salor Distrik Kurik Kabupaten Merauke di laksanakan dngan memberikan materi kepada para peserta pelatihan tentang Undang-undang Informasi teknologi dan transaksi elektronik yang mendukung upaya Promosi pariwisata melalui teknologi, kemudian para peserta mendapatkan materi terkait tata cara mendapatkan Hak paten Produk pariwisata 1000 musamus. Dalam gambar ini pemberi materi berasal dari Dosen Fakultas Hukum Universitas Musamus Ibu Putri Suradinata.,SH.M.H.

\subsection{Pelatihan Strategi E-Promosi wisata 1000 Musamus}

Berikut Bagi Elliott Erwitt, Fotografi menggambarkan sebuah seni observasi. Ini tentang mendapatkan sesuatu tentang yang mengasyikkan di tempat lazimnya. tentang itu tidak akan 
terselip hubungannya dengan hal- hal yang kalian amati dan seluruh wajib dicoba dengan metode kalian melihat mereka. tentang itu tidak bakal terdapat hubungannya dengan hal- hal yang kalian amati serta seluruhnya mesti dilakukan dengan teknik kalian menatap mereka (Kusumo et al., 2019).Kemudian cara yang digunakan untuk memvisualisasikan karya desain secara garis besar ialah dengan memadukan antara foto gambar maupun fotografi yang digunakan selaku media pengambilan foto dengan tata letak maupun layout yang sederhana dan minimalis dengan bermacam elemen (Thionardy et al., 2006). Dalam pengabdian ini, peserta diberikan materi tentang fotografi serta teknik melakukan fotograsi yang baik. Setelah peserta mendapatkan materi, peserta di ajarkan untuk mengambil gambar melalui kamera ponsel masing oleh pemateri.

Di masa sekarang ini, sarana online terlebih khusus media sosial sudah memiliki perkembangan pesat di indonesia. Jangkauan yang sangat mudah melalui sarana gadget untuk mendapatkan informasi dari berbagai belahan dunia. Media sosial memberikan kemudahan kepada para konsumen untuk memperoleh berita yang di anggap sesuai keinginan para nitizen (Ayutiani \& Satria Putri, 2018). Dalam pehaman bartl youtube mempelihatkan sarana yang bisa di akses untuk kebutuhan akademik serta keperluan orang orang dalam menemukan sumber yang diinginkan (Rizky Wardhani, B. Kristiono Soewardjo, 2021). Munculnya youtube memberikan persaingan yang signifikan dengan televisi yang merupakan media informasi yang banyak di pakai oleh masyarakat. Kuatnya alur jaringan internet pada youtube memberikan penawaran mengenai segala referensi informasi yang lebih bervariasi pada televisi.

Di sisi lain, youtube mempunyai kemampuan untuk mejelajah yang sangat kuat untuk berada pada situasi kehidupan masyarakat di jaman moderen ini, hal tersebut disebabkan oleh cara kerja handal youtube yang bisa di temukan melalui sarana komputer, handpone dan lain sebagainya. Youtube muncul menjadi sebuah perbincangan dunia yang memiliki pusat video yang dapat di jangkau serta memiliki fungsi memberi infomasi kepada masyarakat. Kemudian youtube adalah pusat video yang memberikan sarana informasi melalui gambar yang bisa bergerak yang partisipannya dapat mendapatan video ke server youtube serta dapat membagikannya kepada masyarakat. Selanjutnya, Promosi agrowisata dicoba guna menambah jumlah wisatawan,membagikan data kepada wisatawan yang sudah tiba, dan juga mengingatkan wisatawan supaya mengadakan kunjungan kembali (Yoezer, 2015). Pengelola kampung wisata bisa menerapkan promosi guna menambah jumlah wisatawan dengan teknik memanfaat media sosial selaku media promosi serta di kemas secara menarik, karna tentang ini sanggup menarik calon wisatawan untuk mendatangi kampung wisata (OKTAVIANI, 2018). Dalam pengabdian ini, pemateri pemberikan informasi kepada pserta melalui cara pembuatan akun youtube. Peserta diberikan cara membuat email, seteah email para peserta jadi mereka di arahkan untuk login ke yotube pada sarana komputer maupun handpone, selanjutnya mereka membuat chanel youtube mereka dengan memberikan penamanaan yotube selanjutnya ketika akun youtube peserta sudah jadi, mereka di ajarkan cara mengaplod video mereka melalui akun youtube tadi.

Internet adalah suatu sarana yang sangat penting untuk menyalurkan informasi pariwisata daerha. Sarana yang ada dalam informasi internet yang selalu di akses oleh para wisatawan yaitu website (Putra et al., 2020). Website merupakan suatu sarana promosi yang sangat handal, website mempunyai jangkauan dari sis waktu serta tempat yang sangat tidak dapat dibatasi oleh apapuan. Agar mendapatkan website sebagai sarana yang efektif dalam mendistribusikan informasi, di harapkan untuk menerapkan cara nyata agar aktifitas promosi melalui website yang di jalankan mendapat hasil yang baik. Koneksi internet perlu di manfaatkan untuk mendapatkan pengguna dalam jumalah yang banyak, karena perkembangan internet saat ini sebagai sarana promosi serta informasi berkembang meningkat pesat (Surentu et al., 2020). Dalam pengabdian masyarakat ini, dilakukan pemberian materi kepada para peserta tentang cara mebuat website. Para peserta di ajarkan tentang cara mebuat website khususnya website wisata 1000 musamus. Para peserta di giring untuk membuat website pertama, menentukan jenis website yaitu website promosi wisata, kedua menentukan platform website, ketiga menentukan nama website, kempat menginstal wordpress dan kelima optimalisasi pengaturan website. Seanjutnya para peserta di berikan materi tentang cara penggunaan website. Dengan pemberian materi ini para peserta juga di ajarkan bagaimana cara 
mengelola website agar konsisten dalam memberikan informasi.
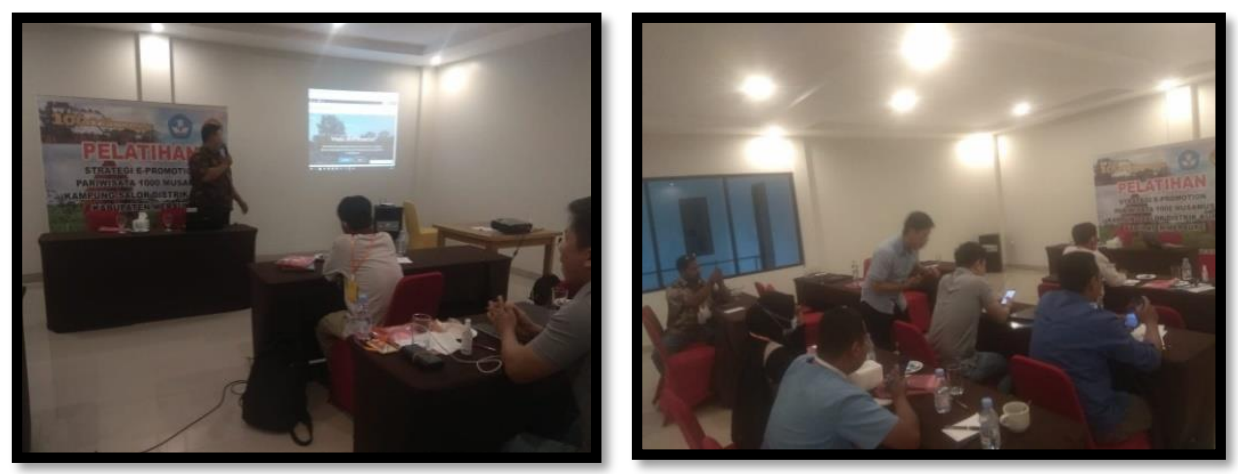

Gambar 2. Kegiatan pelatihan

Dalam gambar di atas menjelaskan bahwa di gambar sebelah kiri para peserta di berikan pelatihan untuk membuat website serta cara mengelola website dengan pemateri Yudhistira Kuncoro adi dari pusat Informasi dan teknologi LPPM universitas musamus, dan gambar sebelah kanan para peserta mendapatkan pelatihan terkait teknik mengambil gambar dan video yang baik dan benar, pemateri yaitu Bapak fajar Arfid suhendra Pegiat fotografer Kandara Merauke.

\section{KESIMPULAN}

Pengabdian ini menemukan jawaban dari rumusan permasalahan, berupa Strategi EPromotion Pariwisata 1000 Musamus Kampung Salor Distrik Kurik Kabupaten Merauke. Dalam pelaksanaan kegiatan pengabdian masyarakat ini, para peserta mendapatkan materi Undangundang No. 19 Tahun 2018 tentang Perubahan Atas Undang-undang No. 11 Tahun 2008 Tentang Informasi Dan Transaksi Elektronik, undang-undang ini mendukung strategi promosi wisata 1000 musamus di distrik kurik dalam pelaksanaannya peserta mendapat alur materi yang berkaitan dengan dasar hukum berupa asas, konten serta penegakan hukum, selanjutnya, para peserta mendapatkan materi cara mendapatkan hak paten melalui aturan undang undang nomor 20 tahun 2016 yaitu cara mendapatkan hak kekayaan intelektual dari logo wisata 100 musamus. Selanjutnya, para peserta mendapatkan materi tentang youtube dan pelatihan cara pembuatan akun youtube, para peserta di ajarkan untuk mebuat email dan cara pengelola akun yotube mereka sebagai upaya strategi E-promosi wisata, dan selanjutnya para peserta mendapatkan materi tentang website serta di berikan pelatihan cara mengelola website untuk pengembangan promosi wisata 1000 musamus.

\section{UCAPAN TERIMA KASIH}

Tim Pengbadian kepada masyarakat ucapan terima kasih kami sampaikan kepada Pihak Universitas musamus dalam hal ini pihak LPPM universitas musamus yang sudah mendukung kegiatan pengabdian ini melalui pemberian dana pengabdian Dipa unmus tahun 2021.

\section{DAFTAR PUSTAKA}

Alma, B. (2014). Manajemen Pemasaran dan Pemasaran Jasa. : CV Alfabeta.

Atiko, G., Sudrajat, R. H., \& Nasionalita, K. (2016). Analisis Strategi Promosi Pariwisata melalui Media Sosial oleh Kementrian Pariwisata RI (Studi Deskriptif pada Akun Instagram@ Indtravel) Analysis Tourism Promotion Strategy Through Social Media By Tourism Ministry Of Republic Indonesia. Jurnal Sosioteknologi, 15(3), 378-389.

Ayutiani, D. N. \& Satria Putri, B. P. (2018). Penggunaan Akun Instagram Sebagai Media Informasi 
Wisata Kuliner. PRofesi Humas: Jurnal Ilmiah Ilmu Hubungan Masyarakat, 3(1), 39. https://doi.org/10.24198/prh.v3i1.11683

Bahiyah, C. \& Hidayat, W. R. (2018). Strategi Pengembangan Potensi Pariwisata Di Pantai Duta Kabupaten Probolinggo. Jurnal Ilmu Ekonomi, 2, 95-103.

Batubara, M. H., Nurmalina, N., Nasution, A. K. P., Agusmawati, A. \& Maharani, A. (2021). Pelatihan Media Sosial Instagram Untuk Sarana Promosi Ekowisata. JPMA - Jurnal Pengabdian Masyarakat As-Salam, 1(1), 1-8. https://doi.org/10.37249/jpma.v1i1.253

Haryani, T. N. (2020). Pendampingan Kelompok Informasi Masyarakat Desa Sumberdodol Kabupaten Magetan dalam Pengembangan Iklan Pariwisata Desa. Jurnal Pengabdian Kepada Masyarakat, 3(2), 1689-1699.

Kusumo, R. O., Bangsa, P. G. \&... (2019). Perancangan Fotografi sebagai Media Promosi Pariwisata Pantai Kedung Tumpang, Pucanglaban, Tulungagung. Jurnal DKV ..., 1(14). http://publication.petra.ac.id/index.php/dkv/article/view/8716

Machfoedz, M. (2010). Komunikasi pemasaran modern. Cakra Ilmu.

OKTAVIANI, W. F. (2018). The Effectiveness of Social Media as Media Promotion of Village Tourism, Studi Pustaka.

Olivia, H. \& Widarti, W. (2021). Strategi Promosi Festival Desa Wisata Padang Kandis Oleh Dinas Pariwisata Kabupaten Belitung. J-Ika, 8(1), 11-18. https://doi.org/10.31294/kom.v8i1.9430

Puskakom. (2015). Rilis Pers: Hasil Survey "Profil Pengguna Internet di Indonesia 2014" oleh APJII bekerja sama dengan Pusat Kajian Komunikasi Universitas Indonesia. Universitas Indonesia.

Putra, T., Pasaribu, P. \& Wulansari, N. (2020). Pemasaran Wisata Berbasis Website di Nagari Wisata Harau Kabupaten Lima Puluh Kota. ABDI: Jurnal Pengabdian Dan Pemberdayaan Masyarakat, 2(1), 18-27. https://doi.org/10.24036/abdi.v2i1.34

Rangkuti, F. (2013). Strategi promosi yang kreatif dan analisis kasus. Gramedia Pustaka Utama.

Rizky Wardhani, B. Kristiono Soewardjo, H. U. (2021). PROMOSI BUDAYA BETAWI TIONGHOA MELALUI YOUTUBE Rizky. Syntax Literate : Jurnal Ilmiah Indonesia, 6(2), 856-871.

Setiawan, N. A. \& U., F. H. (2014). Strategi Promosi dalam Pengembangan Pariwisata Lokal di $\begin{array}{llll}\text { Desa Wisata } & \text { Jelekong. }\end{array}$ https://doi.org/10.23969/trikonomika.v13i2.613

Soemanagara. (2008). Strategic Marketing Communication. Konsep Strategis dan Terapan. Alfabeta.

Surentu, Y. Z, Warouw, D. M. D. \& Rembang, M. (2020). Pentingnya Website Sebagai Media Informasi Destinasi Wisata Di Dinas Kebudayaan Dan Pariwisata Kabupaten Minahasa. Acta Diurna Komunikasi, 2(4), 1-17. https://ejournal.unsrat.ac.id/index.php/actadiurnakomunikasi/article/view/31117/2984 3

Swastha, B, Irawan, D. M. (2006). Manajemen Pemasaran Modern. Liberty.

Thionardy, L., Ardana, I. G. N. M., Handoko, C. T., Studi, P., Komunikasi, D., Seni, F., Desain, D. \& Petra, U. K. (2006). Perancangan Komunikasi Visual Promosi Kawasan Wisata Loksado Di Kalimantan Selatan Dengan Pendekatan Teknik Fotografi. Jurnal DKV Adiwarna, 1(2), 1-9.

Yoezer, K. (2015). Access to credit by the women of rural Bhutan: A Case Study in Bikhar Village in Trashigang. 